\title{
Pengaruh Macam Media dan Takaran Pupuk Kandang Kambing terhadap Pertumbuhan dan Hasil Sawi Hijau (Brassica rapa L.)
}

\section{The Effect of Different Kinds of Media and Proportion of Goat Manure Applications on the Growth and Yield of Green Mustard (Brassica rapa L.)}

\author{
Helmei Anjarwati ${ }^{1)}$, Sriyanto Waluyo ${ }^{2^{*}}$, Setyastuti Purwanti²) \\ 1) Program Studi Agronomi, Fakultas Pertanian, Universitas Gadjah Mada \\ 2) Departemen Budidaya Pertanian, Fakultas Pertanian, Universitas Gadjah Mada \\ *) Penulis untuk korespodensi E-mail: sriyanto.waluyo@ugm.ac.id.
}

\begin{abstract}
Demand for food crops was expected to increase substantially, include the vegetable crops. Conversion of farmland in Indonesia to urban development reduces the amount of lands available for crops production. Use of fertilizer, especially chemical fertilizers has brought in soil degradation and the loss of equilibrium of a stable soil. It also decreased the product quality of vegetables crops. Growing vegetable crops in small spaces could take to increase productivity for the long-term. Eco-friendly technologies in vegetable cultivation need to be intensified. In reply to this, organic fertilizers in agriculture will be the right solution for retaining productivity of problem soils, reducing the usage of chemical fertilizers, improving vegetable crops productivity. The study was aimed to determine the effect of the growing media and proportion of goat manure applications on the growth and yield of green mustard. The research had been conducted in Ponjong District, Gunungkidul Regency since March until July 2016. The research was arranged in randomized complete design factorial, consisted of two factors. The first factor was kinds of growing media that consisted of four levels : soil, raw rice husk, rice husk charcoal, and sawdust. Then the second factor was proportion of growing media and goat manure that consisted of three levels : without manures, 2:1, and 1:1. The result of experiment showed rice husk charcoal with proportion of goat manures 1:1 was considered affecting the best performance of plant growth such as increasing plant height, leaves, leaf area, fresh weight, and dry weight of green mustards.
\end{abstract}

Keywords : green mustard, Brassica rapa L., growing media, goat manure

\section{INTISARI}

Permintaan pangan semakin meningkat termasuk pada kelompok sayuran. Konversi penggunaan lahan di Indonesia dari sektor pertanian ke sektor non pertanian mempengaruhi luas area tanam yang ada. Hal ini juga berdampak pada penurunan produksi sayuran untuk memenuhi kebutuhan masyarakat. Selain itu, degradasi lahan yang disebabkan oleh penggunaan pupuk anorganik yang berlebihan juga membuat kualitas produk sayuran yang dihasilkan semakin menurun. Pengembangan tanaman sayuran di lahan sempit dapat menjadi pilihan untuk meningkatkan produktivitas sayuran. Teknologi budidaya yang ramah lingkungan terutama pada sayuran perlu digiatkan. Pertimbangan pemilihan media tanam diperlukan untuk menunjang pertumbuhan tanaman sayuran di lahan yang terbatas. Penggunaan pupuk organik 
dapat menjadi alternatif solusi untuk mengurangi ketergantungan terhadap penggunaan pupuk anorganik dalam meningkatkan produktivitas tanaman sayuran. Penelitian ini bertujuan untuk mengetahui kombinasi media tanam dan takaran pupuk kandang kambing yang dapat meningkatkan pertumbuhan dan hasil sawi hijau. Penelitian ini dilakukan di Kecamatan Ponjong, Kabupaten Gunungkidul pada bulan Maret-Juli 2016. Penelitian menggunakan Rancangan Acak Lengkap faktorial yang terdiri dari dua faktor yaitu media tanam (tanah, sekam mentah, arang sekam, dan serbuk gergaji) dan perbandingan media dengan takaran pupuk kandang kambing (tanpa pupuk, 2:1, dan 1:1). Hasil penelitian menunjukkan bahwa perlakuan media tanam arang sekam dengan takaran pupuk kandang kambing 1:1 memberikan pertumbuhan dan hasil sawi hijau yang paling baik, yaitu mampu meningkatkan tinggi tanaman, jumlah daun, luas daun, bobot segar tanaman, dan bobot kering tanaman sawi hijau.

Kata kunci: sawi hijau, Brassica rapa L., media tanam, pupuk kandang kambing

\section{PENDAHULUAN}

Sawi hijau (Brassica rapa L.) sayuran merupakan tanaman hortikultura yang memiliki peran sebagai sumber vitamin dan mineral. Permintaan masyarakat terhadap sawi hijau semakin meningkat. Konsumsi sawi hijau mengalami kenaikan dari 1.304 kg/kapita/tahun pada 2013 menjadi 1.408 kg/kapita/tahun pada 2014 (Susenas, 2016). Produksi sawi hijau di Indonesia meningkat antara 3-7\% per tahun dalam kurun waktu lima tahun dari 2010-2014 dan kemungkinan akan terus mengalami peningkatan setiap tahun.

Sawi hijau layak dikembangkan untuk memenuhi permintaan konsumen. Kondisi wilayah Indonesia cocok untuk budidaya tanaman ini. Menurut Haryanto et al., (2006) dari aspek agroklimat, beberapa wilayah di Indonesia sangat potensial untuk budidaya sayuran, seperti Sumatera, Jawa, sebagian Kalimantan, dan Sulawesi. Masa panen yang relatif singkat dan mudahnya dalam pemeliharaan juga merupakan daya tarik untuk mengusahakan sawi hijau.

Budidaya sawi hijau tidak lepas dari peran media tanam. Media tanam yang sesuai akan mendukung pertumbuhan dan perkembangan sawi hijau dengan baik. Konversi penggunaan lahan di Indonesia dari sektor pertanian ke sektor non pertanian mempengaruhi luas area tanam. Salah satu alternatif budidaya tanaman untuk mengatasi keterbatasan lahan adalah pengembangan budidaya sayuran di lahan sempit, misalnya di lahan perkotaan. Lahan perkotaan umumnya tidak memiliki sejumlah ruang yang cukup untuk penanaman sayuran skala besar. Pengembangan tanaman sayuran di lahan perkotaan dapat dilakukan dengan budidaya pada pot, polibag, atau dapat juga memanfaatkan wadah-wadah bekas 
Helmei Anjarwati et al., / Vegetalika. 2017. 6(1): 35-45

untuk dijadikan tempat penanaman. Media tanam yang akan digunakan juga perlu pertimbangan dari segi ukuran, ekonomi, maupun kemudahan dalam penyediaan. Media yang digunakan harus bersifat porus, ringan, dan memiliki aerasi baik agar dapat menunjang pertumbuhan tanaman dengan optimal. Selain itu, media tanam harus mudah diperoleh dan memiliki harga yang terjangkau.

Pemupukan merupakan faktor penting dalam budidaya tanaman yang menunjang keberhasilan produksi sawi hijau. Menurut Bastari cit. Wijaya (2010) tanaman membutuhkan unsur hara yang selalu tersedia selama siklus hidupnya untuk dapat tumbuh dan berproduksi dengan baik. Degradasi lahan yang disebabkan oleh penggunaan pupuk kimia yang berlebihan mempengaruhi kualitas produk sayuran yang dihasilkan. Budidaya tanaman yang ramah lingkungan perlu digiatkan untuk mengatasi masalah penurunan kualitas lahan.

Penggunaan bahan organik dapat menjadi alternatif solusi untuk mengurangi ketergantungan terhadap penggunaan pupuk kimia dalam meningkatkan produktivitas tanaman sawi hijau. Penambahan bahan organik dalam tanah akan dapat memperbaiki struktur tanah dan meningkatkan stabilitas agregat tanah yang nantinya dapat memelihara aerasi tanah dengan baik dan dapat menunjang peningkatan efisiensi penggunaan pupuk (Hayati et al., 2012). Salah satu jenis pupuk organik adalah pupuk kandang. Menurut Syekhfani (2000) pupuk kandang memiliki sifat yang tidak merusak tanah, menyediakan unsur hara makro dan mikro. Selain itu pupuk kandang berfungsi untuk meningkatkan daya menahan air, aktivitas mikrobiologi tanah, nilai kapasitas tukar kation dan memperbaiki struktur tanah. Salah satu jenis pupuk kandang yaitu pupuk kandang dari kotoran kambing. Menurut Tan (1993), pupuk kotoran kambing memiliki keunggulan dibandingkan dengan pupuk kotoran sapi dan kuda, yaitu memiliki unsur makro Nitrogen $(N)$, Fosfor $(P)$, serta Kalium (K) lebih tinggi. Oleh karena itu perlunya dilakukan penelitian ini untuk mengetahui kombinasi media tanam dan takaran pupuk kandang kambing yang dapat meningkatkan pertumbuhan dan hasil sawi hijau.

\section{BAHAN DAN METODE}

Penelitian dilakukan pada bulan Maret-Juli 2016 di Kecamatan Ponjong, Kabupaten Gunungkidul, Daerah Istimewa Yogyakarta. Alat yang digunakan dalam penelitian yaitu penggaris, alat tulis, ember, cangkul, sekop kecil, gembor, gunting, timbangan digital, oven, gelas ukur, bak persemaian, leaf area meter, termohidrometer, lux meter, dan kamera. Bahan penelitian yang digunakan yaitu benih 
sawi hijau Tosakan, tanah Kompleks Litosol dan Mediteran Merah, sekam padi mentah, arang sekam padi, serbuk gergaji, pupuk kandang kambing, polibag ukuran 25x25 cm, kertas label, dan kantung kertas. Penelitian ini menggunakan rancangan $4 \times 3$ faktorial yang disusun dalam rancangan acak lengkap. Faktor pertama adalah jenis media tanam (M) yang terdiri dari 4 aras yaitu tanah (M1), sekam mentah (M2), arang sekam (M3), dan serbuk gergaji (M4), dan faktor kedua adalah tingkat takaran pupuk kandang kambing $(P)$ yang terdiri dari 3 aras yaitu tanpa pupuk (P0), perbandingan media dan pupuk 2:1 (P1), dan perbandingan media dan pupuk 1:1 (P2). Dari kedua faktor tersebut diperoleh 12 kombinasi perlakuan dan untuk masing-masing media sesuai perlakuan terdiri dari tiga ulangan. Masing-masing satuan percobaan terdiri dari 10 tanaman. Analisis lanjutan menggunakan Uji Jarak Berganda Duncan (Duncan's Multiple Range Test) dengan tingkat kepercayaan $95 \%$.

\section{HASIL DAN PEMBAHASAN}

Penelitian ini dilaksanakan di Kecamatan Ponjong, Kabupaten Gunungkidul pada ketinggian wilayah $\pm 200 \mathrm{mdpl}$ dan jenis tanah Kompleks Litosol dan Mediteran Merah. Lingkungan penelitian memiliki suhu $\pm 28^{\circ} \mathrm{C}$, kelembaban udara $52-71 \%$, serta intensitas cahaya dalam rentang 6000-22000 lux.

Tabel 1. Data kandungan unsur hara pada berbagai media tanam yang digunakan saat penelitian.

\begin{tabular}{|c|c|c|c|c|c|}
\hline \multirow[b]{2}{*}{ No } & \multirow{2}{*}{$\begin{array}{c}\text { Variabel Uji Sampel } \\
\text { Media }\end{array}$} & \multicolumn{4}{|c|}{ Jenis Media } \\
\hline & & Tanah & $\begin{array}{l}\text { Sekam } \\
\text { Mentah }\end{array}$ & $\begin{array}{l}\text { Arang } \\
\text { Sekam }\end{array}$ & $\begin{array}{l}\text { Serbuk } \\
\text { Gergaji }\end{array}$ \\
\hline 1 & $\mathrm{~N}(\%)$ & $0,16 r$ & $0,78 \mathrm{st}$ & $0,82 \mathrm{st}$ & $0,58 \mathrm{sd}$ \\
\hline 2 & $\mathrm{P}(\mathrm{mg} / 100 \mathrm{~g})$ & $224,00 \mathrm{st}$ & $137,00 \mathrm{st}$ & $115,00 \mathrm{st}$ & $122,00 \mathrm{st}$ \\
\hline 3 & $\mathrm{~K}(\mathrm{mg} / 100 \mathrm{~g})$ & $34,00 \mathrm{sd}$ & $101,00 \mathrm{st}$ & $204,00 \mathrm{st}$ & $67,00 \mathrm{st}$ \\
\hline 4 & C-Organik (\%) & $1,14 \mathrm{r}$ & $23,01 \mathrm{st}$ & $6,06 \mathrm{st}$ & $21,96 \mathrm{st}$ \\
\hline 5 & $\mathrm{pH}$ & 7,02 & 7,09 & 7,13 & 6,53 \\
\hline
\end{tabular}

Dari hasil uji media tanam diperoleh hasil bahwa media tanam yang digunakan dalam penelitian mengandung sejumlah hara yang dibutuhkan tanaman. Kandungan unsur Nitrogen $(\mathrm{N})$ dan Kalium $(\mathrm{K})$ pada media arang sekam adalah yang tertinggi (Tabel 1). 
Helmei Anjarwati et al., / Vegetalika. 2017. 6(1): 35-45

Tabel 2. Data kandungan unsur hara pada pupuk kandang kambing yang digunakan saat penelitian.

\begin{tabular}{clcc}
\hline No & \multicolumn{1}{c}{ Variabel } & Pupuk Kambing \\
\hline 1 & $\mathrm{~N}(\%)$ & & 0,67 \\
2 & $\mathrm{P}(\%)$ & & 0,66 \\
3 & $\mathrm{~K}(\%)$ & & 1,39 \\
4 & $\mathrm{C}-$ organik (\%) & & 8,95 \\
5 & $\mathrm{C} / \mathrm{N}$ rasio & & 13,36 \\
\hline Sumber: & Data hasil analisis contoh pupuk di Balai Pengkajian Teknologi Pertanian \\
& Yogyakarta (2016). & &
\end{tabular}

Tabel 3. Tinggi tanaman $(\mathrm{cm})$ pada umur $32 \mathrm{hst}$

\begin{tabular}{lccc}
\hline \multicolumn{1}{c}{ Perlakuan } & Tanpa & Media : Pupuk & Media : Pupuk \\
& Pupuk & $(2: 1)$ & $(1: 1)$ \\
\hline Tanah & $30,58 \mathrm{abc}$ & $31,25 \mathrm{abc}$ & $28,65 \mathrm{abcd}$ \\
Sekam Mentah & $20,73 \mathrm{dc}$ & $24,15 \mathrm{bcd}$ & $22,25 \mathrm{dc}$ \\
Arang Sekam & $21,95 \mathrm{dc}$ & $33,93 \mathrm{ab}$ & $36,45 \mathrm{a}$ \\
Serbuk Gergaji & $19,36 \mathrm{~d}$ & $23,55 \mathrm{bcd}$ & $31,53 \mathrm{abc}$ \\
\hline Interaksi & & $(+)$ & \\
\hline CV $(\%)$ & & 8,1
\end{tabular}

Keterangan: Angka yang diikuti huruf yang sama menunjukkan tidak berbeda nyata pada uji DMRT dengan tingkat kepercayaan 95\%. Tanda (+) menunjukkan adanya interaksi antar perlakuan.

Tinggi tanaman sawi hijau dengan perlakuan media tanam arang sekam dengan takaran pupuk 1:1 (M3P2) memiliki hasil yang tertinggi dari semua kombinasi perlakuan. Hal tersebut dapat disebabkan oleh media tanam arang sekam yang diberi pupuk lebih banyak mampu mendukung pertumbuhan tanaman dengan baik seperti dapat menjaga kelembaban daerah sekitar akar, menyediakan cukup udara, dan dapat menahan ketersediaan unsur hara. Menurut pendapat Wuryan (2008) arang sekam sebagai salah satu bahan organik merupakan media tanam yang dapat menjaga kelembaban. Hal ini disebabkan arang sekam bersifat lebih porous karena memiliki pori-pori makro dan mikro yang hampir seimbang, sehingga sirkulasi udara yang dihasilkan cukup baik serta memiliki daya serap air yang tinggi. Junita et al., (2002) menambahkan bahwa media arang sekam merupakan media yang baik dalam mengikat nutrisi. Kemampuan media untuk menyimpan nutrisi ini akan berpengaruh pada ketersediaan hara dalam media. 
Tabel 4. Jumlah daun (helai) pada umur $32 \mathrm{hst}$

\begin{tabular}{|c|c|c|c|}
\hline Perlakuan & $\begin{array}{l}\text { Tanpa } \\
\text { Pupuk }\end{array}$ & $\begin{array}{c}\text { Media : Pupuk } \\
(2: 1)\end{array}$ & $\begin{array}{c}\text { Media : Pupuk } \\
(1: 1)\end{array}$ \\
\hline Tanah & $7,50 \mathrm{~cd}$ & $8,00 \mathrm{bcd}$ & $8,50 \mathrm{bcd}$ \\
\hline Sekam Mentah & $4,50 \mathrm{e}$ & $8,00 \mathrm{bcd}$ & 8,83 bc \\
\hline Arang Sekam & $5,00 \mathrm{e}$ & $9,00 \mathrm{~b}$ & $10,33 \mathrm{a}$ \\
\hline Serbuk Gergaji & $4,17 \mathrm{e}$ & $7,30 \mathrm{~d}$ & $8,00 \mathrm{bcd}$ \\
\hline Interaksi & & $(+)$ & \\
\hline CV (\%) & & 10,5 & \\
\hline
\end{tabular}

Tanaman sawi hijau pada perlakuan media tanam arang sekam dengan takaran pupuk 1:1 (M3P2) memiliki jumlah daun tertinggi (Tabel 4). Hal tersebut disebabkan oleh media arang sekam pada percobaan ini memiliki kandungan unsur hara $\mathrm{N}$ yang lebih tinggi jika dibandingkan dengan media lainnya (Tabel 1). Selain itu, penambahan pupuk yang lebih banyak juga mempengaruhi struktur arang sekam menjadi lebih baik untuk perkembangan akar sehingga nutrisi dapat terserap dengan optimal. Nutrisi sangat mempengaruhi pembentukan daun, terutama unsur nitrogen (N) (Nicholls, 1989 cit Perwitasari et al., 2012). Menurut Hardjowigeno (1995), tanaman yang cukup mendapat unsur $\mathrm{N}$ dalam tanah akan tumbuh lebih hijau. Lingga (2005), menjelaskan bahwa unsur $\mathrm{N}$ berfungsi untuk memacu pertumbuhan pada fase vegetatif terutama daun dan batang.

Hasil analisis sidik ragam juga menunjukkan ada interaksi antara faktor media tanam dan takaran pupuk kandang kambing terhadap variabel luas daun sawi hijau umur 32 hst. Hasil uji Duncan menunjukkan bahwa perlakuanmedia arang sekam dengan takaran pupuk 1:1 (M3P2) diperoleh nilai luas daun tertinggi dengan luas $1193,84 \mathrm{~cm}^{2}$ (Tabel 5). Luas daun yang tinggi selanjutnya diperoleh pada perlakuan arang sekam dengan takaran pupuk 2:1 (M3P1). Perlakuan pupuk pada media sekam mentah (M2P1, M2P2) memberikan luas daun yang lebih baik dibandingkan perlakuan tanpa pupuk (M2P0). Sama halnya dengan serbuk gergaji, penambahan pupuk pada perlakuan M4P1 dan M4P2 juga mampu meningkatkan luas daun sawi hijau. Pemberian pupuk ke dalam media tanam menambah ketersediaan unsur hara bagi tanaman. Tanaman yang cukup mendapat suplai nitrogen $(\mathrm{N})$ akan membentuk daun yang memiliki helaian lebih luas dengan kandungan klorofil yang lebih tinggi, sehingga tanaman mampu menghasilkan asimilat dalam jumlah yang tinggi untuk mendukung pertumbuhan vegetatif (Wijaya, 2010). 
Helmei Anjarwati et al., / Vegetalika. 2017. 6(1): 35-45

Tabel 5. Luas daun $\left(\mathrm{cm}^{2}\right)$ pada umur $32 \mathrm{hst}$

\begin{tabular}{lccc}
\hline \multicolumn{1}{c}{ Perlakuan } & Tanpa & Media : Pupuk & Media : Pupuk \\
& Pupuk & $(2: 1)$ & $(1: 1)$ \\
\hline Tanah & 575,00 ef & $754,71 \mathrm{~d}$ & $647,46 \mathrm{e}$ \\
Sekam Mentah & $157,97 \mathrm{~g}$ & $605,07 \mathrm{ef}$ & $932,25 \mathrm{c}$ \\
Arang Sekam & $502,17 \mathrm{f}$ & $1057,97 \mathrm{~b}$ & $1193,84 \mathrm{a}$ \\
Serbuk Gergaji & $156,52 \mathrm{~g}$ & $559,78 \mathrm{ef}$ & $809,06 \mathrm{~d}$ \\
\hline Interaksi & \multicolumn{4}{c}{} \\
\hline CV $(\%)$ & 9,03 \\
\hline
\end{tabular}

Keterangan: Angka yang diikuti huruf yang sama menunjukkan tidak berbeda nyata pada uji DMRT dengan tingkat kepercayaan 95\%. Tanda (+) menunjukkan adanya interaksi antar perlakuan.

Hasil analisis sidik ragam menunjukkan ada interaksi antara faktor media tanam dan takaran pupuk kandang kambing pada variabel bobot segar tajuk sawi hijau umur 32 hst. Bobot segar tajuk sawi hijau pada umur 32 hst tertinggi (151,92 gram) didapat dari perlakuan media arang sekam dengan takaran pupuk 1:1 (M3P2) (Tabel 6). Proses pembentukan dan perkembangan organ tanaman sangat dipengaruhi oleh ketersediaan air dan unsur hara dalam media tanam. Junita et al., (2002) menyatakan bahwa media arang sekam merupakan media yang baik dalam mengikat nutrisi. Unsur hara yang berada pada media tanam diangkut melalui air yang terserap oleh perakaran tanaman melalui proses difusi osmosis. Semakin baik hara yang terjerap oleh tanaman, maka ketersediaan bahan utama dalam proses fotosintesis akan semakin baik pula. Proses fotosintesis yang berlangsung dengan baik akan memacu penimbunan asimilat pada tubuh tanaman sawi hijau dan hal tersebut tentu akan berpengaruh terhadap peningkatan bobot segar tanaman. Hal tersebut sejalan dengan pernyataan Sitompul dan Guritno (1995) bahwa bobot segar tanaman dapat menunjukkan aktivitas metabolisme tanaman dan nilai bobot segar tanaman dipengaruhi oleh kandungan air jaringan, unsur hara dan hasil metabolisme.

Tabel 6. Bobot segar tajuk (gram) pada umur $32 \mathrm{hst}$

\begin{tabular}{|c|c|c|c|}
\hline Perlakuan & $\begin{array}{l}\text { Tanpa } \\
\text { Pupuk }\end{array}$ & $\begin{array}{c}\text { Media : Pupuk } \\
(2: 1)\end{array}$ & $\begin{array}{c}\text { Media : Pupuk } \\
(1: 1)\end{array}$ \\
\hline Tanah & $109,64 \mathrm{bc}$ & $118,56 \mathrm{~b}$ & $78,34 \mathrm{e}$ \\
\hline Sekam Mentah & $32,90 \mathrm{~g}$ & $75,19 \mathrm{e}$ & $104,69 \mathrm{~cd}$ \\
\hline Arang Sekam & $51,61 \mathrm{f}$ & $108,63 \mathrm{bcd}$ & $151,92 \mathrm{a}$ \\
\hline Tanah & $34,85 \mathrm{~g}$ & $59,35 \mathrm{f}$ & $96,18 d$ \\
\hline Interaksi & & $(+)$ & \\
\hline CV (\%) & & 8,5 & \\
\hline
\end{tabular}


Tabel 7. Bobot kering tajuk (gram) opada 32 hst

\begin{tabular}{lccc}
\hline \multicolumn{1}{c}{ Perlakuan } & Tanpa & Media : Pupuk & Media : Pupuk \\
& Pupuk & $(2: 1)$ & $(1: 1)$ \\
\hline Tanah & $10,32 \mathrm{~b}$ & $10,67 \mathrm{~b}$ & $6,32 \mathrm{e}$ \\
Sekam Mentah & $3,57 \mathrm{~g}$ & $5,83 \mathrm{ef}$ & $7,93 \mathrm{~d}$ \\
Arang Sekam & $3,99 \mathrm{~g}$ & $9,76 \mathrm{bc}$ & $15,54 \mathrm{a}$ \\
Tanah & $3,42 \mathrm{~g}$ & $4,51 \mathrm{fg}$ & $8,55 \mathrm{~cd}$ \\
\hline Interaksi & \multicolumn{4}{c}{} \\
\hline CV $(\%)$ & \multicolumn{3}{c}{} \\
\hline
\end{tabular}

Keterangan: Angka yang diikuti huruf yang sama menunjukkan tidak berbeda nyata pada uji DMRT dengan tingkat kepercayaan 95\%. Tanda $(+)$ menunjukkan adanya interaksi antar perlakuan.

Penggunaan media arang sekam dengan takaran pupuk 1:1 (M3P2) memiliki bobot kering tanaman yang lebih tinggi dari kombinasi perlakuan lainnya. Perlakuan tersebut memiliki daun yang lebih banyak (Tabel 4) dan luas (Tabel 5). Daun yang luas dan lebar akan menambah kemampuan tanaman untuk menyerap cahaya matahari lebih optimal sehingga proses fotosintesisnya juga optimal. Hasil fotosintat tercermin dalam akumulasi bobot keringnya. Menurut Lakitan (1993) semakin besar luasan daun tanaman maka bobot keringnya pun akan semakin besar. Goldsworthy dan Fisher (1996) menambahkan bahwa pertambahan jumlah daun mengakibatkan luas daun tanaman meningkat. Peningkatan pertumbuhan organ vegetatif tanaman seperti peningkatan jumlah daun, penambahan tinggi tanaman, serta pemanjangan akar dan efisiensi distribusi asimilat tersebut ke bagian-bagian tanaman ini juga akan berdampak pada peningkatan bobot kering tanaman yang terbentuk.

Pada Tabel 8 diperoleh hasil bahwa penggunaan media sekam mentah (M2) dan serbuk gergaji (M4) justru memiliki nilai LAB yang lebih tinggi meskipun hasil statistik menunjukkan tidak ada perbedaan. Hasil tersebut dapat dikarenakan oleh jumlah daun yang banyak dan lebar menyebabkan adanya mutual shading atau daun-daun saling ternaungi sehingga proses asimilasi bahan kering berjalan kurang optimal. 
Helmei Anjarwati et al., / Vegetalika. 2017. 6(1): 35-45

Tabel 8. Laju Asimilasi Bersih ( $\left./ \mathrm{cm}^{2} / \mathrm{minggu}\right)$

\begin{tabular}{lc}
\multicolumn{1}{c}{ Perlakuan } & $\begin{array}{c}\mathrm{LAB} \\
\left(\mathrm{g} / \mathrm{cm}^{2} / \mathrm{ming} \mathrm{gu}\right)\end{array}$ \\
\hline Media Tanam: & $0,006 \mathrm{a}$ \\
Tanah & $0,007 \mathrm{a}$ \\
Sekam mentah & $0,005 \mathrm{a}$ \\
Arang sekam & $0,007 \mathrm{a}$ \\
Serbuk gergaji & $0,008 \mathrm{a}$ \\
\hline Takaran Pupuk: & $0,006 \mathrm{a}$ \\
Tanpa Pupuk & $0,005 \mathrm{a}$ \\
Media : Pupuk (2:1) & $(-)$ \\
Media : Pupuk (1:1) & 11,0 \\
\hline Interaksi & \\
\hline CV (\%) & \\
\hline Keterangan: Angka yang diikuti huruf yang sama menunjukkan tidak berbeda nyata pada uji \\
\multicolumn{1}{c}{ DMRT dengan tingkat kepercayaan 95\%. Tanda $(+)$ menunjukkan adanya } \\
interaksi antar perlakuan.
\end{tabular}

Laju asimilasi bersih (LAB) adalah kemampuan tanaman menghasilkan bahan kering hasil asimilasi tiap satuan luas daun tiap satuan waktu (g/dm²/minggu) (Gardner et al., 1991). Menurut Gardner et al. (1991) daun-daun bagian atas menyerap radiasi paling banyak, sehingga memiliki laju asimilasi yang tinggi, sedangkan daun-daun yang lebih tua pada dasar tajuk dan ternaungi oleh daun di atasnya mempunyai laju asimilasi yang lebih rendah.

Tabel 9. Indeks Konsumsi

\begin{tabular}{lccc}
\hline \multicolumn{1}{c}{ Perlakuan } & Tanpa & Media : Pupuk & Media : Pupuk \\
& Pupuk & $(2: 1)$ & $(1: 1)$ \\
\hline Tanah & $95,9 \mathrm{~b}$ & $95,8 \mathrm{~b}$ & $95,9 \mathrm{~b}$ \\
Sekam Mentah & $96,2 \mathrm{~b}$ & $96,4 \mathrm{ab}$ & $95,8 \mathrm{~b}$ \\
Arang Sekam & $97,2 \mathrm{a}$ & $95,8 \mathrm{~b}$ & $96,5 \mathrm{ab}$ \\
Tanah & $97,3 \mathrm{a}$ & $96,7 \mathrm{ab}$ & $96,0 \mathrm{~b}$ \\
\hline Interaksi & \multicolumn{4}{c}{} \\
\hline CV $(\%)$ & & $(+)$ & \\
\hline
\end{tabular}

Keterangan: Angka yang diikuti huruf yang sama menunjukkan tidak berbeda nyata pada uji DMRT dengan tingkat kepercayaan 95\%. Tanda (+) menunjukkan adanya interaksi antar perlakuan.

Indeks konsumsi menggambarkan nilai perbandingan antara bagian tanaman yang dapat dikonsumsi dengan bobot total tanaman. Indeks konsumsi sawi hijau termasuk tinggi karena hampir seluruh bagian tanaman (tajuk) dapat dikonsumsi kecuali akar. Nilai Indeks Konsumsi berdasarkan uji statistik dari tanaman sawi hijau pada perlakuan arang sekam dan serbuk gergaji tanpa pupuk (M3P0, M4P0) didapatkan nilai tertinggi (Tabel 9). Hal tersebut terjadi karena pada perlakuan tersebut, penyaluran asimilat untuk pembentukan tajuk tanaman lebih banyak dibandingkan ke bagian perakaran. Sedangkan pada perlakuan lainnya, tanaman sawi hijau kemungkinan menyalurkan asimilat dengan seimbang untuk membentuk seluruh 
organ tanaman.

\section{KESIMPULAN}

Penggunaan media tanam arang sekam dengan takaran pupuk kandang kambing 1:1 memberikan pertumbuhan dan hasil sawi hijau yang paling baik.

\section{DAFTAR PUSTAKA}

Gardner, F. P., B.R Pearce., dan R. Mitchell. 1991. Fisiologi tanaman budidaya. UI Press, Jakarta.

Goldsworthy, P.R. dan N.M. Fisher. 1996. Fisiologi tanaman budidaya tropik. Penerjemah: Tohari. Gajah Mada University Press, Yogyakarta.

Hardjowigeno, S. 1995. IImu tanah. Akademika Pressindo, Jakarta.

Haryanto, B., Suhartini, T., Rahayu, E., dan Sunarjo. 2006. Sawi dan selada. Penebar Swadaya, Jakarta.

Hayati, E., Sabarudin., dan Rahmawati. 2012. Pengaruh jumlah mata tunas dan komposisi media tanam terhadap pertumbuhan setek tanaman jarak pagar (Jatropha curcas L.). Agrivista. 3:129-134.

Junita, F., S. Muhartini., dan D. Kastono. 2002. Pengaruh frekuensi penyiraman dan takaran pupuk kandang terhadap pertumbuhan dan hasil pakchoi. Jurnal IImu Pertanian 2002. IX

Komarayati, S dan G. Pari. 2014. The combination of additions of biochar and wood vinegar on jabon and sengon growth. Jurnal Penelitian Hasil Hutan. 1:12-20.

Lakitan, B. 1993. Dasar-dasar fisiologi tumbuhan. PT. Raja Grafindo Persada, Jakarta.

Lingga, P. 2005. Hidroponik, bercocok tanam tanpa tanah. Penebar Swadaya. Jakarta.

Perwitasari, B., M. Tripatmasari., dan C. Wasonowati. 2012. Pengaruh media tanam dan nutrisi terhadap pertumbuhan tanaman pakchoi (Brassica juncea L.) dengan sistem hidroponik. Agrovigor. 1: 14-25.

Sitompul, S.M. dan B. Guritno. 1995. Analisis pertumbuhan tanaman. Gadjah Mada University Press, Yogyakarta.

Susenas. 2016. Konsumsi per kapita dalam rumah tangga setahun menurut hasil susenas.<https://aplikasi2.pertanian.go.id/konsumsi/tampil susenas kom2 th.p hp>. Diakses 1 April 2016.

Syekhfani. 2000. Pertanian organik: suatu alternatif menuju sistem pertanian berkelanjutan (ditinjau dari aspek kesuburan tanah). Dinas Pertanian Tanaman Pangan, Jawa Timur.

Tan, K. H. 1993. Environmental soil science. Marcel Dekker. Inc, New York.

Wijaya, K. 2010. Pengaruh konsentrasi dan frekuensi pemberian pupuk organik cair hasil perombakan anaerob limbah makanan terhadap pertumbuhan tanaman sawi (Brasicca juncea L.). Skripsi. Universitas Sebelas Maret, Surakarta. 
Helmei Anjarwati et al., / Vegetalika. 2017. 6(1): 35-45

Wuryan. 2008. Pengaruh media tanam terhadap pertumbuhan tanaman hias pot Spathiphyllum sp. Buletin Penelitian Tanaman Hias. 2: 81-89. 